\title{
INTRODUCTION TO THE THEMATIC SECTION
}

\author{
Andreja VEZOVNIK
}

Around 15 years have passed since the early 2000s when the first groups of migrants that did not come exclusively from the area of ex-Yugoslavia began to cross Slovenia's borders. At that time the Slovenian media responded xenophobically, appealing for protection against these "invasive aliens" that appeared to be so different from "us" (see Pajnik 2008). However, this was not a break from their established patterns. Throughout the past 25 years, scholars have demonstrated how the Slovenian mainstream media have not succeeded in transcending the dominant modes of depicting "the other". Whether "the other" stands for migrants, Roma people, Bosnian migrant workers, refugees, Muslims, the Erased etc., the dominant discourses and rhetoric seem to stay the same. Several scholars have shown that the "other" is represented as threatening, barbaric, culturally and even physically different and therefore perceived as an invasive threat to Slovenian cultural, national, ethnic and racial homogeneity (see Doupona, Verschueren, Žagar 2001; Žagar 2004, 2009; Pajnik 2003, 2007, 2008; Vidmar Horvat 2007; Vezovnik 2013, 2015a, 2015b, 2017; Bobnič, Vezovnik 2013; Kralj 2008; Mlekuž 2008; Bajt 2016; Jalušič 2001; Kuzmanić 1999; Pušnik 1999, 2003, 2008). In rarer cases the "other" has also been depicted as a submissive, desubjectivised suffering victim calling for the reader's compassion (Vezovnik 2013, 2015a, 2015b).

During the so-called "migrant crisis" which occurred in autumn 2015, the dominant Slovenian political and media discourses once again did not change much. As soon as the first migrants entered Slovenia, the media started to re-construct the xenophobic discourses, calling for even more "efficient" security measures against what they termed "the migration flood".

It all began as the consequence of the closure of the Hungarian border. On 15 September 2015, a humanitarian corridor through Croatia and Slovenia was established in order to allow migrants from Syria, Afghanistan, Iraq, Pakistan etc. to transit the "Balkan migratory route" and reach target destinations in western and northern European countries that were previously accessed through Hungary. Migrants were suddenly forced to change their route, which initially led across Turkey, Greece, Macedonia, Serbia, Bulgaria, and Hungary (Lunaček, Brumen, Meh 2016). The first group of approximately 200 migrants arrived in Slovenia by train from Croatia on 17 September 2015. The migrants were mainly aiming to transit Slovenia and continue their journey to Austria. However, from the first days when refugees started to enter Slovenian territory it became clear that the Slovenian government was unprepared to handle the logistics of registering and properly caring for the migrants by providing them with medical support, food, shelter, psychological support and transportation to Austria. According to Kogovšek and Bajt (2016: 8), the capacities of the Slovenian reception centres were far too low. The lack of organization and adequate decision making led to the additional dehumanization of the migrants, who had to wait long hours for registration, transport and reception of humanitarian aid. Throughout the autumn of 2015, the arrivals of refugees were not constant but depended on the opening 
and closure of the Hungarian border, which affected the so-called "western Balkans migratory route". According to government data, the number of migrants crossing Slovenia was 422,724 in the period from 17 October 2015 to 25 January 2016, with a peak in October and November. $48.7 \%$ of them were men, and $51.3 \%$ were women and children. $45 \%$ came from Syria, 30\% from Afghanistan, 17\% Iraq, 7\% from other countries and 1\% from Pakistan. Amongst them, 158 refugees applied for international protection, 69 applications were evaluated but only 5 persons were granted refugee status.

Things became even more problematic when the government realized that most of the refugees would not be applying for asylum in Slovenia, and that the Croatian authorities would not be willing to accept them when returned (Kogovšek, Bajt 2016: 8). The situation became especially complicated when the Slovenian government tried to meet the Schengen and EU requirements for the further securitization of the Schengen Area and the establishment of the humanitarian corridor at the same time. Finally, amongst other things, the Schengen requirements led to the decision of the Slovenian government to erect a razor-wire fence on the Slovenian-Croatian border in November 2015. The razor wire was a part of a broader European securitization plan which also foresaw the deployment of police forces in full riot gear, including weapons, changing the law in order to give more power to the military, detaining migrants at Refugee Centres or in monitored fenced areas at the Slovenian-Croatian border crossings etc. (Ladić, Vučko 2016: 25). Although the humanitarian corridor was established precisely because of the abrupt closure of the Hungarian border with a razor-wire fence that prevented the migrants from trespassing across Hungarian territory, the Slovenian securitization measures led to the adoption of the same "security” measures. Orban's much-criticized policies became the Slovenian reality (or better, normality) a couple of months later.

Throughout the whole period of Slovenia's involvement in the "Balkan migratory route", the media and political discourses played a crucial role in shaping and constructing images of migrants and migration in the Slovenian public imagination. However, the dominant political and media discourses did not establish the imagery of migration in isolation, but worked together. The Slovenian political strategy, which mainly focused on the implementation of successful securitization measures, was entirely in line with the Slovenian mainstream media constructions of refugees as a security, economic and cultural threat that needs to be controlled (see Vezovnik 2017). The media discourses also went hand in hand with even more explicit practices and rhetoric of exclusion, such as racism and hate speech, which were mainly associated with right-wing political discourses and which were perpetuated in conservative right-wing media and online (see Bajt 2016), especially on popular social-media platforms such as Twitter and Facebook.

This section therefore provides insight to a very problematic juncture of media and political discourses on migration. The empirical material that the authors of this section critically engaged with was obtained from the Government Communication Office in the form of hard-copy press clippings that included all printed and transcribed TV texts published and aired between 20 August 2015, when the "Balkan migratory route" came into existence, and 31 December 2015, when the humanitarian corridor began to close down. The media that the authors of this section addressed included the following print media: Slovenske novice, Delo, Dnevnik, Večer, Reporter, and Demokracija, and the TV show Odmevi, which is aired by the national public broadcaster RTV Slovenija. The articles that comprise the section make an empirical analysis of the selected material using various 
methodological and analytical approaches, from critical discourse analysis and framing to more theory-based interpretative approaches.

The section starts with an article by Ksenija Vidmar Horvat that provides a broader picture of the migration situation in Slovenia and Europe by analysing public reactions to the migrant situation. Vidmar Horvat claims that during the migration situation, Slovenia assumed the role of the border guard of Europe, structured on the basis of memories of its socialist past. She explores Slovenian "post-Schengen" imaginaries of the border and finds that the historical legacies of the divided Europe of the $20^{\text {th }}$ century still played a part in negotiating the identity of the region. The article emphasizes that the securitization of migration emerged as one of the dominant modes in the analysed public responses. The depiction of migrants as a threat to Slovenians that needs to be securitized is also demonstrated by the second article, written by Andreja Vezovnik. In her analysis of the Slovenian tabloid daily Slovenske novice, Vezovnik finds that Slovenians are constructed as the victims of the migrant's alleged cultural differentness, barbarity, and criminality. In explaining the phenomenon of self-victimization, Vezovnik explores the self-identification of Slovenians as victims. In her view, such self-identification, which mainly appeared in canonical literature and emerged since the spring of nations in the mid-19 century, lays the groundwork for the understanding of self-victimization in the present day. The rhetoric of threat, fear and hate is further explored by Maruša Pušnik in her article, in which she analyses populism and extremism in moralistic stories in Reporter and Demokracija - Slovenia's two leading right-wing weeklies. Pušnik's findings in her exploration of the Slovenian right-wing press are similar to Vezovnik's findings relating to Slovenia's main tabloid. Pušnik claims that the discussions on migrants and Islam in such media are extremely xenophobic, nationalist, racist and chauvinist. If such problematic rhetoric can somehow be expected to be found in tabloid and right-wing journalism, it surely appears as an even bigger problem when found in the so-called "quality" press and on public TV. The articles by Breda Luthar, Mojca Pajnik and Dejan Jontes deconstruct journalistic mechanisms in order to show how the media followed the mainstream political agenda in preserving the idea of "Fortress Europe". Luthar explores how naturalized and conventionalized rules of positing a lack of bias as a constitutive element of journalists' professional self-representation influenced the covering of migration topics. In her analysis of RTV Slovenija's show Odmevi, Luthar finds out the selection and "discursive treatment" of the interviewed guests led to a "opinion corridor" - i.e. a narrowing of the debate on migration, which led to the exclusion of any voices but those coming from the political mainstream. Similarly, Pajnik discovers a very problematic fusion of the media with the political agenda, which she outlines in her analysis of op-ed articles in Delo. She demonstrates how the articles adopt a "realist" political stance in the absence of a more informed analysis that would increase the reader's understanding of European migration policies. The section concludes with an analysis of Delo, Dnevnik, and Večer conducted by Jontes. He focuses on journalistic conventions, the formal aspects of the news stories, and the performance of objectivity. By analysing "factism" and episodic framing, Jontes reflects on the paradox in reporting migration issues where the problem is primarily framed in terms of humanitarian crisis on the explicit level, and rarely as a security issue, while on the connotative level, factism and episodic framing suggest another reading of the problem that reinforces fear of immigrants. 
We believe that this section mainly shows three things. First, it shows how the mainstream media completely gave up the floor to dominant political voices and worked as channels through which these voices became hegemonic. However, the media not only provided a space for such articulations, but actively contributed to shaping them, primarily by cutting out the voices of migrants and critical sub-political figures. Second, it shows how the mainstream media failed to critically address and question dominant political structures, ideologies, policies and ideas. Third, it shows the problematic continuation of xenophobic, racist, stereotypical, chauvinist, nationalist and similar rhetoric that still persists as the dominant framework through which Slovenian mainstream media depict and represent "the other".

\section{REFERENCES}

Bajt, Veronika (2016). Anti-Immigration Hate Speech in Slovenia. Razor-Wired: Reflections on Migration Movements through Slovenia in 2015 (eds. Neža Kogovšek Šalamon, Veronika Bajt). Ljubljana: Peace Institute, 51-62.

Bobnič, Robert, Vezovnik, Andreja (2013). Diskurz o islamu ali dispozitiv izjav in objekta: Primer islamskega versko-kulturnega centra. Časopis za kritiko znanosti 40, i.e. 41/251, 34-53.

Doupona Horvat, Marjeta, Verschueren, Jef, Žagar, Igor Ž. (2001). Retorika begunske politike v Sloveniji: Pragmatika legitimizacije. Ljubljana: Mirovni inštitut.

Jalušič, Vlasta (2001). Ksenofobija ali samozaščita? Poročilo skupine za spremljanje nestrpnosti (ed. Brankica Petković). Ljubljana: Mirovni inštitut, 12-43.

Kogovšek Šalamon, Neža, Bajt, Veronika (2016). Introduction. Razor-Wired: Reflections on Migration Movements through Slovenia in 2015 (eds. Neža Kogovšek Šalamon, Veronika Bajt). Ljubljana: Peace Institute, 7-10.

Kralj, Ana (2008). Nezaželeni? Medijske in politične konstrukcije tujcev v Sloveniji. Dve domovini / Two Homelands 27, 169-190.

Kuzmanić, Tonči (1999). Bitja s pol strešice: Slovenski rasizem, šovinizem in seksizem. Ljubljana: Mirovni inštitut.

Ladić, Maja, Vučko, Katarina (2016). Slovenia’s Response to Increased Arrivals of Refugees: We Don't Want Them, But We Also Don't Understand Why They Don't Want to Stay. Razor-Wired: Reflections on Migration Movements through Slovenia in 2015 (eds. Neža Kogovšek Šalamon, Veronika Bajt). Ljubljana: Peace Institute, 15-30.

Lunaček Brumen, Sarah, Meh, Ela (2016). „Vzpon in padec« koridorja. Časopis za kritiko znanosti XLIV/264, 21-45.

Mlekuž, Jernej (2008). Čapac.si, or on burekalism and its bites: An analysis of selected images of immigrants and their descendants in Slovenian media and popular culture. Dve domovini / Two Homelands 28, 23-37.

Pajnik, Mojca (2003). Poročanje medijev o marginaliziranih skupinah. Socialno delo 42/2, 87-94.

Pajnik, Mojca (2007). Medijske podobe o beguncih. Socialno delo 46/1-2, 1-11.

Pajnik, Mojca (2008). Mnenja o migrantih v tisku: Potreba po korektivu javnomnenjskega raziskovanja. Annales. Series hitoria et sociologia 18/1, 219-232. 
Pušnik, Maruša (1999). Konstrukcija slovenske nacije skozi medijsko naracijo. Teorija in praksa 36/5, 796-808.

Pušnik, Maruša (2003). Moralizacija kot estetski projekt dokumentarnega žurnalizma: O urbanih legendah, meganormalnosti in globokem tovarištvu. Teorija in praksa 40/2, 267-286.

Pušnik, Maruša (2008). Narrating and doing otherness through the aesthetics of media texts. Multicultural dilemmas: Identity, difference, otherness (eds. Wojciech Kalaga, Marzena Kubisz). Frankfurt am Main: P. Lang, 129-139.

Vezovnik, Andreja (2013). Representational discourses on the Erased of Slovenia: From human rights to humanitarian victimization. Journal of language and politics 12/4, 606-625.

Vezovnik, Andreja (2015a). Balkan immigrant workers as Slovenian victimized heroes. Slavic Review 74/2, 244-264.

Vezovnik, Andreja (2015b). Ex-Yugoslavian immigrant workers in Slovenia: Between Balkanization and victimization. Dve domovini / Two homelands 41, 11-22.

Vezovnik, Andreja (2017, forthcoming). Securitizing Migration in Slovenia: A Discourse Analysis of the Slovenian Refugee Situation. Journal of Immigrant and Refugee Studies.

Vidmar Horvat, Ksenija (2007). Piramidalna napaka: Medijska cenzura in televizijski raizem informativno-zabavne oddaje Piramida. Dialogi 43/78, 131-148.

Žagar, Igor Ž. (2004). How "refugees” became “illegal migrants". Journal of Intercultural Communication 7, http://www.immi.se/intercultural/nr7/zagar.htm.

Žagar, Igor Ž. (2009). The (re)construction of refugees in Slovenian media. Discourse and transformation in Central Eastern Europe (eds. Aleksandra Galasinska, Michal Krzyzanowski). New York: Palgrave Macmillan, 75-92. 